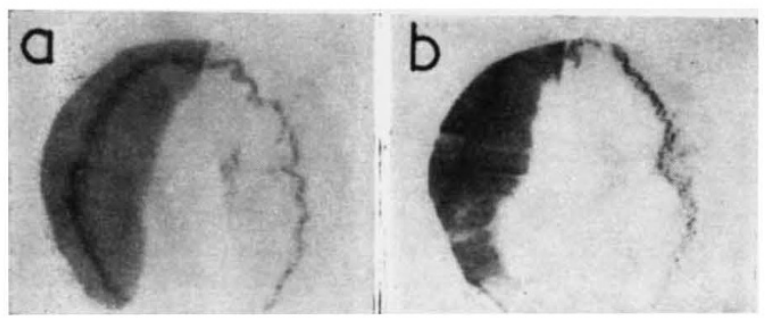

Fig. 1. Effect of phrenicotomy on fixation by $a$-bungarotoxin labelled with iodine-131 after 14 days $(a)$ and 60 days $(b)$. Right side: innervated hemidiaphragm; left side: phrenicotomized hemidiaphragm. Each rat was injected subcutaneously with $0.3 \mu \mathrm{g} / \mathrm{g}$ of $\alpha$-bungarotoxin and died at $75 \mathrm{~min}(a)$ and $110 \mathrm{~min}(b)$ respectively after the injection.

end-plate zone remained unchanged even after more than $4 \mathrm{~h}$ of washing with Tyrode solution, whereas the portion of toxins taken up non-specifically by the muscle tissue other than the motor end-plate zone disappeared almost completely after washing. This finding is consistent with the irreversible nature of the neuromuscular block by these toxins.

By cutting the left phrenic nerve we examined the influence of denervation on the localization of these toxins in the rat diaphragm. At 14 and 60 days respectively after phrenicotomy, the labelled toxins were injected subcutaneously in a dose of $0.3 \mu \mathrm{g} / \mathrm{g}$ body weight and the autoradiograph of the denervated side was compared with that of the intact right side of the diaphragm. In the hemidiaphragms denervated for 14 days, the radioactivity spread over the whole area of the muscle tissue, although a well defined motor end-plate zone could still be distinguished (Fig. 1a). This finding, together with that of Waser ${ }^{8}$ using C14-curarine, gives support to the contention that supersensitivity of denervated muscles to acetylcholine results from an increase in the receptor area rather than from a marked change in the receptors themselves $^{9,10}$. In contrast to the finding of Waser ${ }^{8}$ that in the denervated diaphragms the radioactivity disappeared completely within 60-120 days, we found almost the same pattern of localization of radioactivity in the hemidia. phragm denervated for 60 days (Fig. $1 b$ ).

C. Y. LEE

L. F. TSENG

Т. Н. СHIU

Pharmacological Institute,

College of Medicine,

National Taiwan University,

Taipei, Taiwan.

Received July 10, 1967 .

'Chang, C. C., and Lee, C. Y., Arch. Intern. Pharmacodyn. Ther., 144, 241 (1963).

'Lee, C. Y., and Chang, C. C., Intern. Symp. Animal Venoms, São Paulo. Brazil (1966).

${ }^{3}$ Su, C., Chang, C. C., and Lee, C. Y., Animal Toxins, 259 (Pergamon Press,

- Chang, C. C., and Lee, C. Y., Brit. J. Pharmacol. Chemother., 28, 172 (1966).

${ }^{\circ}$ Lee, C. Y., and Tseng, L. F., Toxicon, 3, 281 (1966).

'Lee, C. Y., Tseng, L. F., and Chiu, T. H., Seventh Intern. Cong. Biochem., Tokyo (1967).

- Waser, P. G., and Lüthi, U, Arch. Intern. Pharmacodyn. Ther., 112, 272 (1957).

8 Waser, P. G., J, Pharm. Pharmacol.,12, 577 (1966).

- Axelsson, J., and Thesleff, S., J. Physiol., 147, 178 (1959).

${ }^{10}$ Miledi, R., J. Physiol., 151, 1 (1960).

\section{Progesterone in Cerebrospinal Fluid during Human Pregnancy}

Progesterone has been found to be an effective anaesthetic agent when given intraperitoneally to animals ${ }^{1,2}$ and 21 hydroxy pregnandione succinate has been used clinically for general anaesthesia ${ }^{3}$. Of practical importance in clinical anaesthesia is the fact that in animals pro. gesterone potentiated the effect of ether and chloroform ${ }^{2}$.
No clinical confirmation of this effect in humans is, however, available. Paradoxically, it is believed that progesterone renders the respiratory centre more sensitive to carbon dioxide and that this may account for the lowered $p \mathrm{CO}_{2}$ in blood during pregnaney.

In view of the higher concentration of progesterone in the peripheral circulation during pregnancy and the apparent lack of clinical effects on the central nervous system, we were interested to obtain some information concerning the concentration of progesterone in the cerebrospinal fluid especially in pregnancies approaching term. A search of the literature revealed that this information had not previously been reported.

The method which we used to assay the progesterone in cerebrospinal fluid was identical to that used for plasma ${ }^{4}$. The highest reliable sensitivity obtained with the method was $0.004 \mu \mathrm{g} / \mathrm{ml}$. Using this method we confirmed that the concentration of progesterone in the peripheral blood rises progressively during pregnancy and that there is no reduction in concentration until separation of the placenta ${ }^{5}$. It is now generally believed that there is no reduction of progesterone in the peripheral blood before the onset of labour at term.

Peripheral blood and cerebrospinal fluid were obtained at the same time from each of four patients at term. In each case the cerebrospinal fluid was obtained before the administration of spinal anaesthesia. The results of the assays are shown in Table 1.

$\begin{array}{ccc}\text { Tatient } & \begin{array}{c}\text { Table 1 } \\ \text { Progesterone } \\ \text { in plasma } \\ (\mu \mathrm{g} / 100 \mathrm{ml} .)\end{array} & \begin{array}{c}\text { Progesterone in } \\ \text { cerebrospinal fluid } \\ (\mu \mathrm{gg} / 100 \mathrm{ml} .)\end{array} \\ & 10.00 & \text { Undetectable } \\ B & 8 \cdot 74 & 0.30 \\ B & 9.00 & 0.55 \\ D & 11.10 & \text { Undetectable }\end{array}$

The results strongly suggest that there is an effective blood-brain barrier for progesterone and this may explain the lack of apparent effect on the central nervous system as pregnancy advances. The marked difference in concentration of progesterone has also been shown to exist for cortisol $^{6}$, and it is interesting that the concentration of cortisol found by Baron and Abelson in cerebrospinal fluid is similar to that reported here for progesterone.

This work was supported by the General Research Support Grant to the Lying-in Division of the Boston Hospital for Women from the US Public Health Service, Department of Health, Education and Welfare.

Department of Biological Chemistry, Aron O. Lurie

Harvard Medical School and

Boston Hospital for Women.

Department of Anaesthesiology,

Jess B. Weiss

Boston Hospital for Women and

Harvard Medical School.

Received May 15, 1967.

' Selye, H., Endocrinology, 30, 437 (1942).

¿ Selye, H., J. Pharmacol. Exp. Therap., 73, 127 (1941).

${ }^{3}$ Murphy, F. J., Guadagni, N. P., and DeBon, F., J. Amer. Med. Ass., 158, $1412(1955)$.

Lurie, A. O., Villee, C. A., and Reid, D. E., J. Clin. Endocrinol. and Met., 26, 742 (1966).

Surte, A. O., Reid, D. F., and Villee, C. A., Amer. J. Obst. and Gynec., 96, 670 (1966).

Baron, D. N., and Abelson, D., Nature, 173, 174 (1954).

\section{Effects of Norepinephrine on Tissues of the Frog Heart Atrium poisoned by Tetrodotoxin}

THE acceleration of the sinus venosus of the frog's heart induced by epinephrine may be the result of an increase in the conductance of sodium ${ }^{1}$. We also know that the action potential of the frog atrium is abolished in sodium 